\title{
Schoolteachers' Resisted Images: Facing Stereotypes and Affirming Identities
}

\author{
Pilar Méndez ${ }^{1}$ \\ ${ }^{1}$ Science and Education Faculty, Doctoral Programe Studies in Education, Universidad Distrital Francisco José de \\ Caldas, Bogotá, Colombia \\ Correspondence: Pilar Méndez, Universidad Distrital Francisco José de Caldas, Calle 25 No. $43^{\text {a }} .49$ Apto. 301, \\ Bogotá, Colombia. Tel: 473-2852. E-mail: pmendez@udistrital.edu.co
}

Received: November 17, 2017

Accepted: January 30, $2018 \quad$ Online Published: April 27, 2018

doi:10.5539/ies.v11n5p100

URL: https://doi.org/10.5539/ies.v11n5p100

\begin{abstract}
This paper aims to explore teachers' resistance practices in Colombia for affirmation purposes. It reveals how resistance practices have contributed to arguing against some imposed labels and stereotypes during different periods of time. Archaeology was the toolbox used to trace statements in teachers' voices from several documentary sources that built the archive. As a result, three important images were identified: the first was linked to the idea of teaching as vocation and the consideration of teachers as priests; the second referred to teaching as a profession and their own struggles to be recognised as subjects of knowledge, and the third one referred to their rejection of teaching defined as a function where teachers are considered technicians that meet functions.
\end{abstract}

Keywords: images, stereotypes, resistance, power, practices, dominant discourses

\section{Introduction}

Not much work has been done worldwide to theorize the productive force of teachers' resistance practices in their own self-constitution as subjects of knowledge. Some works have focused on teachers' resistance to change and reform (Hargreaves, 2005, Harvey, \& Broyles, 2010; Berkovich, 2011), teachers' identity (Brooks, 2016; Bukor, 2015; Bazzul, 2016), teachers' struggles for recognition (Jenlink, 2014), teachers' conflicts with state, policies, and rules, but little attention has been focused on resistance as the main concern in the sense of self-constitution. This paper problematizes views of resistance as an unbeatable practice. It is on the same wavelength as Foucault's idea of resistance as a power relation that undergoes complexity, contradictions, tensions and negotiations. I want to highlight that this local view of Colombian school teachers' resistance practices within the framework of a historical perspective teased out invisible sides of their constitution. This view means mapping the complexity of these practices, looking at contending claims of dominant discourses.

Archaeology here worked as a powerful toolbox to trace dominant discourses (social, political, and economic) about how teachers are perceived, and the roles demanded of them regarding identity positions, roles, and work practices. The ways teachers contested these dominant discourses showed the complicated scenario to achieve recognition, participation, and acceptation. Indeed, traditional forms of struggle (striking, protest) and even the same teacher union association proclaimed effective in the past are critically rejected by some teachers without denying their importance to claim better working conditions and higher wages. At this point, it is important to notice how several strategies are enacted by teachers, some of them effective and some negative -in terms of how these actions affected their images- but certain resistance practices are executed to alter an image for affirmation and positioning.

The self-images that have emerged from teachers' resistance practices were a matter of concern in this study, which implied recognizing that teacher form has been shaped by different forces (state, society, politics, economics, academics) that prescribe who/how the teacher should be and how he/she should teach; in other words, determining ways of being and acting to be 'a good teacher'. In this arena, the teacher resists and defines his subjectivity, affirming or rejecting some of its aspects while defending particular conditions of existence.

Reviewing the literature about resistance (Sabato, 2000, Foucault, 1976; Giroux, 1983; Touraine, 1995), notions such as power, freedom and struggle emerge and show the conditions of the possibility of a variety of relationships, 
responses, reactions between subjects, objects and institutions. Depending on individuals' understanding of dominant discourses, sometimes this power/resistance duo may produce self-domination, subordination and, more importantly, resistance. To exercise resistance is an option of power performance. In fact, we all possess the capacity to practice resistance but what leads an individual to resist?

Resistance often arises from people's attempts to face domination. This domination operates through discourse. Dominant discourses have different forms that label people, set roles, rank identities. The way individuals react to them is important to understand how individuals are objectified, which transforms human beings into subjects (Foucault, 1982). In his essay Subject and Power, Foucault asserts: 'there are two meanings of the word 'subject': subject to someone else by control and dependence; and tied to his own identity by a conscience or self-knowledge' (p. 781). In this latter respect, there are noticeable practices of self-knowledge to struggle against the power effects of someone else's control. In fact, human beings are not entirely determined by practices of domination; they are free to modify, refuse or accept those rules intended to govern them (Giroux, 1983; Sábato, 2000). This idea of power circulating is suitable to tackle how teachers' concrete practices of resistance have contributed to the government of themselves (Ball \& Olmedo, 2013; Ball, 2015) to trace how teachers think of themselves, accept/use a label as an image or refuse it. Although some contradictions might result in this process of identification, labels play an important role in the struggles to work on oneself and the construction of one's identity (Appiah, 2005). In brief, this paper focuses on schoolteachers' struggles against labels, revealing how some of them are used or confronted to affirm themselves.

\section{Method}

This study employed the Foucauldian perspective of archaeology as a tool box to understand how some teachers' images have been historically constituted, affecting the social consideration of teachers. The particularity of this revision set the conditions to tackle discontinuities in different documentary sources. Archaeology organized the description of the teachers' resistance archive, which means to order scattered discourses into correlated discursive formations.

\subsection{Procedures}

\subsubsection{Eventalisation}

It is regarded as a move backwards served as a genealogical principle that changes the cause-effect explanations given to historical facts to claim continuities. Eventalisation acts here with a different view, instead of explaining events as continuities, it allows the tracing of discontinuities; in other words, to explain the emergence of events as thresholds. In this case, the struggles for the organization of Unions during the 1930s were identified as a crucial event to trace teachers' discursive practices to negotiate their 'right to organize themselves in this type of labour forces'. Henceforth, the exercise of analysing different documents implied the disarticulation of books, laws, and oeuvres to identify statements whose reiteration facilitates the construction of a polyhedron of intelligibility (Foucault, 1969). Precisely, it was the exercise of disarticulating the presumed unity of discourses that allowed me to identify different force lines resulting from other types of discourses (economic, political, social) that have played a part in the organization of education affecting not only the way it has been organized, but the way teachers are perceived.

The emergence of a particular event and no other is possible due to situations whose conditions are reconfigured by lines of force that intervened to accommodate power mechanisms to make them work in different directions. In this sense, the growing polymorphism of these forces meant explaining what happens to Colombian teachers in a relational form that disaggregates the resistance process into different parts to avoid the cause-effect explanations. As Foucault explains: every discursive formation does not belong (necessarily, at least) to only one of these systems, but enters simultaneously into several fields of relations, in which it does not occupy the same place, or exercise the same function (1969, p. 177).

\subsubsection{Instrumentalisation of Discursive Registers}

According to Zuluaga (1998, p. 183) this stage entails the localization and recollection of a documentary net, in which teachers' voices and discourses that talk about them could be traced. Here, it was important not only to work on institutionalised documents or the ones with public recognition and prestige but with those that have been ignored and invisible.

\section{1) Pre-Reading of Registers}

This approach seeks to establish relations between documents of different natures to reveal something new in the analysis; for instance, a practice derived from a law whose objective was not established. The comparison between documents is crucial to force types of relations before being ignored by the chronological disposition of events. 


\section{2) Thematisation}

This stage consists in the identification of recurrent themes that consolidate a discursive domain. The most important procedure here is an analytical type of reading to locate, relate and integrate meanings resulting from statements scattered in different documents. The findings are set out on a perceptual grid. According to Foucault (1969):

Archaeological study is always in the plural; it operates in a great number of registers; it crosses interstices and gaps; it has its domain where unities are juxtaposed, separated, fix their crests, confront one another, and accentuate the whitespaces between one another (...) But it may also, by a sort of lateral rapprochement (as in The Order of Things), put into operation several distinct positivities, whose concomitant states are compared during a particular period, and which are confronted with other types of discourses that have taken place at a given period (174-175).

\subsection{Corpus}

Images, labels and stereotypes of school teachers in different types of documents (texts and discourses) were relevant in conducting this study. As the Historical Discourse Analysis puts forward, I as a researcher traced statements that constituted objects and subjects. Around 140 teachers' journals (including newspapers and novels), 110 normative documents (plans, laws, decrees and ministers' memories), 100 news items in national presses, were analysed and about 40 international and national documents were consulted as a means to understand how a particular period of time favored a register over other.

\subsection{Research Design}

Although Foucault refers to archaeology as a toolbox avoiding the term methodology, this type of documentary research has been framed by others as a historical Discourse Analysis (HDA), (Denzin \& Lincoln, 2018), and for some others with the term Analytics of Government (Dean, 1999; Meskus, 2009; Rose, 1999). This design is useful for examining historical statements and regularities that are relevant for a period of time. In this research, how teachers were identified by others and by themselves implied the establishment of an analysis where discontinuities were valuable to explain the preference for a statement over the abandonment of another (Chartier, 2006). This procedure operates due to characterization of strategic guidelines to identify a discursive formation capable of articulation of a descriptive system of analysis (i.e. economy, education, and politics.). Thus, one has the identification of a system made possible to explain the colonization of a force (economy, politics) over education to intervene in teachers' images and adapt them to an economic or political program.

\section{Results}

Bearing in mind the historical processes in the constitution of schoolteachers, some images in the way of recognising teachers were unveiled by identifying some statements despite the different terms found to label them. Table 1 illustrates the most prominent images resisted by school teachers: 
Table 1. Images resisted vs. constructed. Provided by the author

\begin{tabular}{|c|c|c|}
\hline $\begin{array}{l}\text { 1930-1950 } \\
\text { Vision of teaching }\end{array}$ & Image resisted & Image constructed by teachers \\
\hline Vocation & Priest, moral guidance, conformist & Public worker/unionized teacher \\
\hline $\begin{array}{l}1950-1977 \\
\text { Vision of teaching }\end{array}$ & Image resisted & Image constructed by teachers \\
\hline Vocation-Profession & $\begin{array}{l}\text { An apostle } \\
\text { Communist } \\
\text { Lazybones }\end{array}$ & $\begin{array}{l}\text { Professionals } \\
\text { Dignified salaries }\end{array}$ \\
\hline $\begin{array}{l}\text { 1980-1994 } \\
\text { Vision of teaching }\end{array}$ & Image resisted & Image constructed \\
\hline Pedagogic-Knowledge based & $\begin{array}{l}\text { Marginal teacher } \\
\text { Mere technician }\end{array}$ & $\begin{array}{l}\text { Intellectual } \\
\text { cultural worker } \\
\text { Pedagogues }\end{array}$ \\
\hline $\begin{array}{l}\text { 2002-2015 } \\
\text { Vision of teaching }\end{array}$ & Image resisted & Image constructed \\
\hline Teaching as a function & $\begin{array}{l}\text { De-pedagogues } \\
\text { Marginal teacher-mediocre, } \\
\text { undervalued }\end{array}$ & $\begin{array}{l}\text { Highly qualified } \\
\text { and pedagogically prepared. }\end{array}$ \\
\hline
\end{tabular}

The historical characteristics surrounding teachers' lives are merged with socio-cultural, political and economic reasoning that this study discussed using the historically predominant images. The images I came across with will be listed as follows:

\subsection{The Image of Teachers as Priests}

Teachers' struggles to organize themselves into unions during the 1930s outlined particular configurations in terms of how teachers perceived themselves and how these perceptions were or were not aligned with more general ones. The image of teachers by that time was closely related to the moral example and guidance of a priest and, teaching was considered a service vocation to be accepted regardless of the working conditions to do the job. The working conditions of teachers were extremely detrimental to teachers' financial support of very basic needs. In this sense, teachers were inspired by the workers' unions of the time and some social sectors and even the media to claim their right to be organized in unions. In doing so, some discursive practices were exercised to seduce teachers to be unionized while these same practices were directed to the society to get its support and reduce some prejudices towards unions. The strategic component of these discursive practices revealed the subjected image of teachers as priest and moral models which confront the image of a teacher as a member of a union.

As a result of these practices towards teachers' organization new problems emerged in which once gained the right to be unionized, teachers confronted themselves with more crucial problems linked to identification processes. The thematisation process carried out warns us of the emergence of discourse formations to identify unions more connected to the localisation of teaching than to a knowledge commonly shared (i.e. First zone Union of Bogotá, seventh zone union Girardot, Teachers' Association of Boyacá). Up to this point, the period 1930-1949 is essential to tracing teachers' resistance practices linked to struggles for rights and improvement of working conditions in which the antagonism of forces between the images of teachers as priests and as unionised workers were confronted.

The effects of being unionised were multiple: on the one hand teachers go on strikes, hold violent and peaceful demonstrations, engage in cessation of activities, among other activities to receive immediate attention from the Colombian State and obtain benefits. On the other, these activities were considered illegal and connected to communistic ideologies and vagrancy. As a result, the image of unionised teachers was openly criticized (see table 1). So, they were stereotyped as idle and lazy teachers.

The way teachers defined the teaching profession differed in form and content from the definitions provided by the state in different decrees. The strategic component of teachers' discursive practices during this event revealed meditated practices of self-recognition as professionals' worthy to be certified as special ones with dignified conditions of stability, promotion and capacitation. The numbers of strikes and protests increased considerably during this period (1959-1980) where thanks to teachers' actions teaching career was included in a special regime of recruitment, promotion and retention. 


\subsection{The Image of Teachers as Cultural Workers and Intellectuals}

Teachers acknowledged education as a political endeavour and, as well, the importance of their role to govern the teaching exercise and influence society. In doing so, a group of teachers fought against the more traditional union practices, reorienting them to a more political and emancipatory activism where pedagogy was crucial to the reaffirmation of themselves as subjects of knowledge, making it visible how pedagogy had been relegated to a subaltern discipline.

The pedagogical movement as a current of thought that seeks to recover the cultural role of the teacher in a liberating horizon will not risk pedagogical romanticism (...) Our search, therefore, is not simply the recreation of pedagogical and cultural knowledge; we intend to place it in its rightful place within the general context of the struggle for a new political and cultural hegemony. It is not, therefore, in the interest of pedagogy that the educator should forget his role as a wage earner and citizen and neglect the struggles that he must continue to fight as such. (CEID-FECODE, Revista Educación y Cultura, 1984, p. 17)

Discursive practices such as: the legitimation of pedagogical knowledge, the recognition of different types of knowledge and practices, the cultural component of intellectual work of teachers and the political value of their actions were used to dismantle the stereotyped view of teachers as lazybones and interested only in their economic benefits. The image of unionized teachers changed, and it became politically accepted for a considerable period. These insights were significant to create the general law of education in the country, where once again teachers were called upon to participate in its redaction.

The idea of teachers as technicians, whose work was basically to implement what experts in curriculum had designed -according to educational reforms by the time-was denounced by teachers as the image of the marginalised teacher. Marginalization was used to explain how mechanisms of oppression and exclusion were executed by policymakers and the most conservative society, subjugating her/his role to a mere consumer of policies and plans (Calonge, P. y Quiceno, H., 1984; Martínez Boom, A., 1987; De Tezanos, A., 1984; Zuluaga, 1985).

\subsection{Teachers as Technicians Who Meet Functions}

The definitions of teaching as a function that can be carried out by any professional changed the conditions of teaching exercise and affect the social consideration of teachers as possessors of a specialized knowledge. Hegemonic practices over a teaching career, its objects, subjects and practices as a part of the influence of the neoliberal attack on education (Giroux, 2010; Weiner, L., \& Compton, M., 2008) redefined the way education around the globe was conceived. The introduction of business 'quality control' measures in education (Weiner \& Compton) introduced new concepts to think of teachers. In this respect, the way professionalism was articulated to teaching (competitiveness, efficacy, quality) made it possible for the professionals of other fields to be employed as teachers.

Teachers' resistance practices were oriented to denounce the de-professionalization of the teaching career, the abandonment of pedagogy as a central core of teaching, the abandonment of education as a project of culturalisation and the loss of confidence in the conditions to exercise teaching. The common place to judge educators is now relocated in this frame of not being sufficiently prepared to do the job, not being totally engaged with the competitive vision of education, and not being controlled to obey and correspond to the global enterprise.

\section{Discussion}

The social consideration of school teachers has been affected by different lines of force (political, economic, cultural, and educational), including the power-resistance practices (actions or non-actions) of teachers and their organisations. Each epoch configures discursive regularities that happen in a space-time, giving place to pretensions of knowledge and truth, and product of an historical context promoted by the intricate relations of events that affect society. Discursive practices used to categorise and stereotype do not value neutral category making (Ramirez-Berg, 2002); these value-laden images can be positive or negative (stereotypes) and their social validation can be a result of an exercise of power to affirm a positive image or to refuse a stereotypical one.

As can be noticed, the dominant image of a priest was useful to maintain the status quo of a series of events that helped Colombian society to respect teachers as trustworthy moral leaders who help maintain the political and sociocultural principles to raise a family, nourish a nation, and promote/foster a literate society. As part of the cultural traditions that characterised the country during this time (1930-1950), religion and politics worked together to ensure society's obedience. The image of teacher as a priest enjoyed prestige and respect and at the same time guaranteed submission to this noble activity as a vocation of service. In this sense, teachers accepted poor work conditions, low salaries and orders as part of this apostolate. 
When teachers found themselves overwhelmed by the economic situation that deprived them of very basic needs such as buying food, paying services, transport, etc., they realised the importance of the promotion of teaching as a kind of work worthy to be praised and well paid. In this sense, the strategic component of their pleadings assimilated the tone and the force of the working-class fights to gain society's sympathy but, also, mainly to dismantle in their own teachers' mind the effect of this subordinate position. Here, resistance to dominant discourses involved the practice of different forms of organization, i.e. unions, movements, and individual actions. We can regard these actions as mere strategies of opposition if one only pays attention to the effects of replying, but it is another matter when we unveil their significance in terms of subjectivation to understand the acceptance or refusal decisions (conscious or unconscious) of being subjugated and controlled by someone else or by self-government practices.

Later on, this image of being unionised and stereotyped as lazybones, exacerbated by the unions practices (strikes, demonstrations, etc.), was related to communism and considered illegal acts. As a result, political and societal speeches against these illegal acts affected the ways unionised teachers were perceived. Laws to punish teachers on strikes emerged, so the right to exercise protest had to be and still must be defended. At the time, teachers' struggles for the professionalization of the teaching career were misunderstood by a sector of the population, while the other sector was still concerned with the loss of the social consideration of teachers. These acts may appear to be contradictory, but they reflect how hegemonic practices internalized in people's mind an image that stereotyping is a powerful tool to subject someone to an identity and decrease her/his social esteem. In this sense, for instance, Popkewitz (2015) has explained how the curriculum has been used for policy-makers to execute social regulation and normalisation of people.

During the 1980s, the most prominent struggle emerged when teachers decided to fight for their right to govern their work. This event was highly productive. It produced the emergence of movements, differences and resistance as power exercises, where teachers used their knowledge to defend and legitimate themselves as cultural workers. This power of infused-discourse (Bazzul, 2016) served to constitute a type of teacher subject more related to education as a political commitment. The work of this pedagogical movement turned the spotlight on the need for a different consideration of teachers in terms of their potential to become intellectuals. This powerful resistance influenced positively the way teachers were considered. Pedagogy and research became important action fields to exercise teaching and laws and institutions' plans incorporated them as professional practices to be learnt and promoted in education programmes around the country. The understanding of resistance as a practise makes it possible to analyse how teachers perceive themselves in their relation to objects (laws, institutions, knowledge and subjects) (students, inspectors, colleagues) to affirm, reject and control important aspects of their lives e.g. their social recognition as holders of knowledge and the consideration of teaching as a profession, among others. This relational view portrays the complex net or relations in which teachers are immersed and the different points that affect their constitution as subjects. Although in this scenario it seems there is no space for acting, what it is really interesting about the question for the subject constitution could be explained in Touraine's words: 'The subject is an individual's will to act and to be recognized as an actor' (1995, p. 207). Precisely, this will to act reveals the freedom subjects have to take responsibility for themselves and for their society (Touraine, 1995, p.203). That is why resistance appears as an attempt to liberate teachers of social constraints and pre-established roles.

The 2002-2012 decade was decisive to trace the following statement: the idea that teaching is a profession in crisis, and that the teacher is responsible for the existing low quality of education. In this idea, teachers are no longer recognised as intellectuals and also are not well prepared to face the new demands in times of globalisation and competitiveness. The epistemological status of the teaching profession, cemented in the validity of human and pedagogical views of education, has been replaced by other terminology: efficacy, competitiveness, quality, and efficiency. The teacher as a subject of knowledge is losing esteem. This consideration does not circulate as it once did but persists obscured in the media and political documents. Indeed, teachers' voices reclaiming pedagogy as an empowering discipline to educate children, adolescents and even professionals with an emancipatory view of education seemed ignored by a society who has naturalized capitalism and its model of education. What it is important here is the way teachers' struggles subsist and are intended to face this market-like education system, unveiling how it produces inequality and exclusion of the less favoured sectors of society and affects the consideration of education in which a teacher is a protagonist (see appendix 1).

\section{Conclusions}

The archive of this research made it possible to identify, analyse, and describe some images about teachers in government plans, laws, norms, union discourse, and expert voices which have been constructed to identify teachers and understand the teaching career (apostle, idle person, cultural worker, and intellectual, among others). It revealed ways to see and make teachers see differently, depending on the regime of truth established in an era in 
the strategic field of struggles and small devices that give rise to the intervention of their subjectivity. Here, resistance practices are validated as a scenario for analysing the ways in which teachers themselves struggle for conditions of possibility, being affected but, as well, affecting other relationships. This research shows how teachers resistance practices to dominant discourses involves the practice of active and passive forces to face stereotypes and affirm some images, showing how some of these images coexist, overlap and operate as an approval or disapproval force to define teachers, in spite of some contradictions and contingencies.

The interest in subject constitution deals with a subject's work on the self, which inevitably is connected to the notion of identities. What this work showed is how teachers' struggles strengthen or refuse labels, roles or stereotypes. My focus on resistance allowed me to show how different images have been constructed, shifted and subjected to change (Hall, 1996; Gee, 2001; Phan, 2008), here subjectivity is seen as the terrain of resistance that creates the possibility of thinking differently and questioning accepted assumptions about teaching and teachers (Giroux, 1983; Ball \& Olmedo, 2013).

\section{References}

Appiah, A. K. (2005). The Ethics of Identity. Princeton: Princeton University Press.

Ball, S. J. (2015). Subjectivity as a site of struggle: Refusing neoliberalism? British Journal of Sociology of Education, 37(8), 1129-1146. https://doi.org/10.1080/01425692.2015.1044072

Ball, S. J., \& Olmedo, A. (2013). Care of the self, resistance and subjectivity under neoliberal governmentalities. Critical Studies in Education, 54(1), 85-96. https://doi.org/10.1080/17508487.2013.740678

Bazzul, J. (2016). The Constitution of Subjectivities: Discourse, Practices, and Repetition. In Ethics and Science Education: How Subjectivity Matters (pp. 7-22). Cham: Springer International Publishing. https://doi.org/10.1007/978-3-319-39132-8_2

Berkovich, I. (2011). 'No, we won't! Teachers' Resistance to Educational Reform.' Journal of Educational Administration, 49(5), 563-578. https://doi.org/10.1108/09578231111159548

Brooks, C. (2016). Teacher Subject Identity in Professional Practice. Routledge, NY.

Bukor, E. (2015). Exploring Teacher Identity from a Holistic Perspective: Reconstructing and Reconnecting Personal and Professional Selves. Teachers and Teaching: Theory and Practice, 3(21), 305-327. https://doi.org/10.1080/13540602.2014.953818

Calonge, P., \& Quiceno, H. (1984). El maestro marginal. Revista Educación y Cultura, 1(2), 64-67.

Calonje, P. (1986). El círculo del tiempo y los maestros. Revista Educación y Cultura, 3(7). Bogotá.

CEID-FECODE. (1984). Editorial. Revista Educación y Cultura, 1(1), 17-41.

CEID-FECODE. (1984, julio). Movimiento Pedagógico. Otra escuela, Otros maestros. Educación y Cultura, 1(1), 4-20

CEID-FECODE. (2002). La Contrarreforma en Marcha. Nuevo Estatuto Docente. Estándares y Evaluación. Educación y Cultura, 61, 2-24.

Chartier, R. (2006). Escribir las prácticas. Buenos Aires: Manantial

De Tezanos, A. (1984). Por qué un Movimiento Pedagógico? Educación y Cultura, 1(1), 12-19.

Dean, M. (1999). Govermentality: Power and rule in modern society. London: Sage

Deleuze, G. (1988). Foucault. Minneapolis: University of Minnesota Press.

Deleuze, G. (2015). La subjetivación. Curso sobre Foucault. Tomo III, trad. cast. Ires y Puente, Cactus, Buenos Aires.

Denzin, \& Lincoln. (2018). The SAGE Handbook of Qualitative Research (5th ed.). USA. Sage Publications.

El colombiano. (1950, 12 de septiembre). El Maestro y La Vida Social. Medellín, pág. 4.

El Tiempo. (1971, 28 de septiembre). Editorial. pág. 4. Bogota.

Foucault, M. (1969, 1972). The Archaeology of Knowledge and the Discourse on Language. Pantheon Books, New York.

Foucault, M. (1979, 1976). The History of Sexuality (Volume 1: An Introduction). London: Allen Lane.

Foucault, M. (1982). The Subject and Power. Critical Inquiry, 8(4), 777-745. https://doi.org/10.1086/448181

Gee, J. P. (2001). Identity as an analytic lens for research in education. Review of Research in Education, 25, 
99-125.

Giroux, H. (1983). Theory and Resistance in Education: A Pedagogy for the Opposition. South Hadley, MA: Bergin and Garvey.

Giroux, H. (2010, October 16). The neoliberal attack on education. Retrieved from http://www.truth-out.org/opinion/item/12126-can-democratic-educationsurvive-in-a-neoliberal-society

Hall, S. (1996). Who needs 'identity'? In S. Hall, \& P. du Gay (Eds.), Questions of Cultural Identity (pp. 1-17). London, Sage.

Hargreaves, A. (2005). Educational Change takes Ages: Life, Career and Generational Factors in Teachers' Emotional Responses to Educational Change. Teaching and Teacher Education, 21(8), 967-983. https://doi.org/10.1016/j.tate.2005.06.007

Harvey, T. R., \& Broyles, E. A. (2010). Resistance to Change: A Guide to Harnessing its Positive Power. New York: Rowman \& Littlefield.

Jenlink, P. (2014). Teacher Identity and the Struggle for Recognition: Meeting the Challenges of a Diverse Society. UK: Rowman and Littlefield Education.

Kusch, M. (1991). Foucault's strata and fields. An investigation into archaeological and genealogical science studies. Synthese 1 Library. https://doi.org/10.1007/978-94-011-3540-5

Marroquín, S. (1934, 20 de julio). Editorial. Voceros de las inquietudes del magisterio del Huila. Neiva Periódico 'El esfuerzo'. Año 1.

Martínez, B. A. (1987). Movimiento Pedagógico: un movimiento por el saber y la cultura. Revista Educación y Cultura, Separata Especial, 73-76.

Medrano, L. (1949). Informe del Departamento Normalista. En Memoria del Ministro de Educación Nacional, Dr. Arango, Eliseo. República de Colombia. Prensas del MEN.

Meskus, M. (2009a). Governing risk through informed choice: Prenatal testing in welfarist maternity care. In S. Bauer, \& A. Wahlberg (Eds.), Contested categories: Life sciences in society (pp. 49-68). Farnham, UK: Ashgate.

Nieto, A. (1935). La Educación. Revista Educación. Órgano de la facultad de Educación de la Universidad Nacional, $3(24$ y 25). Bogotá.

Phan, L.-H. (2008). Teaching English as an international language: identity, resistance and negotiation. Clevedon, UK: Multilingual Matters.

Popkewitz, T. S. (2015). The reason of schooling: Historicizing curriculum studies, pedagogy, and teacher education. New York, NY: Routledge.

Ramirez-Berg, Ch. (2002). Latino Images in Film: Stereotypes, Subversion, Resistance (pp. 13-37). Austin: University of Texas Press.

Rodríguez, C. (2013). Grupo todo sobre los docentes 1278 (2014, 15 de febrero). [Facebook.com] Retrieved from https://www.facebook.com/TodoSobreLosDocentes 1278

Rose, N. (1999). Powers of freedom: reframing political thought. Cambridge, UK. Cambridge University Press, Cambridge. https://doi.org/10.1017/CBO9780511488856

Sábato, E. (2000). La Resistencia. Editorial Planeta, Seix Barral. Argentina.

Touraine, A. (1995). Critique of Modernity. Blackwell's, Oxford, UK.

Weiner, L., \& Compton, M., (2008). The Global Assault on Teaching, Teachers, and their Unions: Stories for Resistance. Palgrave Macmillan, Basingstoke, UK. https://doi.org/10.1057/9780230611702

Zuluaga, O. (1985). El trabajo histórico y la recuperación de la práctica pedagógica. Revista Educación y Cultura, 2(3), 66-72. 


\section{Appendix 1}

\section{Excerpts samples}

1930-1950

-The teacher should be a priest, an apostle, sufficiently prepared to do this patriotic and noble labour (Marroquín, 1934, p. 1).

-To the teacher, we have asked, before anything, neatness in his life, in his person, in the environment of his school and his home (Nieto, A. 1935. p.429).

-The teacher is an apostle that wants and knows to be a model of virtue, patriotism and heroic self-denial (Medrano, L. 1949. En MEN p. 48).
The Colombian teacher must also be an advisor, a driver in the respective radius of his activities; his moral and mental authority must serve him in the affirmation of his social influence: such a personality cannot be depressed, cannot be isolated, cannot be subject to the whims of any quicker, higher will, but must acquire rights that serve as a stimulus for their work and a guarantee for their future (Revista Educación, 1933 1(2), p. 122).

1950-1977

-Dignify the noble profession and stimulate it, because otherwise embracing the career of the magisterium is going to become an attempt of suicide, is almost like declaring a hunger strike (El Colombiano, 1950, p.4).

- 'The magisterium had to move away from educational activity any attempt at communism because it goes against the Church of Christ, against the democratic government of Colombia and against the social dignity of the Colombian people' (El Colombiano, 1951, p. 2).
-As we said at the beginning of the analysis, the exercise of the teaching activity is a profession which, as such, has philosophical, scientific, technical and ethical principles that differentiate it from the profession of a lawyer, a physician, a priest, an engineer, etc. Therefore, the different professionals must respect the other fields and adjust to the limitations of their professional training (SCEE, 1972, p 235).

The legal, socio-economic and political frameworks of our country prevent you from advancing in your profession and obtaining remuneration commensurate with your work, your needs and the demands of the environment. This situation discourages him, it increases the degree of dissatisfaction, the mysticism is lost as the reality of life shows him that the 'apostolate' does not reach him or his family to satisfy personal needs, social demands and professionals (SCEE, 1972)

1980-1994

Educational technology has condemned the teacher to be 'a technician', 'an applicator', 'an organizer of the curriculum' and this implies a reduction of her/his possibilities, the impossibility of being thought of as an intellectual, as an individual capable of relating to science, art, literature, and all kinds of disciplines; capable of producing and carrying out important transformations in their practice (Calonje, P., 1986. REC, 3 (7), p.15).

The Administration Manual Curriculum for primary education describes what are called and provide 'evidence of the administrative and pedagogical work of teachers and administrators '(MEN, 1979, p. 89). ...when the teacher is clear and aware of her/his role as an intellectual who participates in the political and cultural direction, and has been able to understand and appropriate the historically constructed knowledge that determines and gives character to her/his profession: pedagogy. That is why the movement of teachers can only be pedagogical (CEID, 1984. REC, 1 (1), p. 22).

-The pedagogical project moves in two planes of struggle: one, in front of the State, and another inward, in the work of the teacher and the school. On the first front, it encompasses fighting the battle for democracy, that in the particular case of education is cemented in the freedom of teaching or of professorship; then in respect to the autonomy of the teacher, in independence with regard to the government around the control and orientation of the programs and their contents (CEID, 1984, REC, 1(1), p.3).

$2002-2015$

Teachers do not really prepare as they should, but they are ready for demonstrations, stoppages and protests
The pretension, according to which professionals from other disciplines can replace teachers in their functions, 
for their salary. They can do postgraduate courses at the expense of the state to improve their level, but they are lazy, work part time (that is why they are paid part time), are ignorant, clumsy and syndicalists. Most look like truckers and guises, they should get to work instead of running strikes and protest (blogger's opinion, 2012).

In Colombia the careers related to teaching are chosen by those who score the worst scores in Saber 11 (A national Test), who, in turn, reflect the same performance at the end of the university, in Saber Pro (A national test to Undergraduate students); this is worrisome because they are the ones who will have the responsibility to train the new students (Rodríguez, C. researcher of the Compartir Foundation, El Tiempo, 2013).

Note

Note 1. Excerpts in Table 1 were original in Spanish.

\section{Copyrights}

Copyright for this article is retained by the author(s), with first publication rights granted to the journal.

This is an open-access article distributed under the terms and conditions of the Creative Commons Attribution license (http://creativecommons.org/licenses/by/4.0/). in fact undermines the constituent principle of pedagogy as the founding knowledge of the teaching profession (CEID, FECODE, 2002. REC, (61), p. 2).

It is not understood how professionals of education are defined as professionals with different qualifications, legally qualified for the exercise of the teaching function, as if the competences for the performance of teaching could be enabled by a legal norm and not by valid titles and knowledge accumulated and produced (CEID-FECODE, 2002. REC, (61), p.23).

The opening of teaching to other professions can be a useful and even necessary measure to promote in the school institution the circulation and exchange of different approaches and looks ... But such openness cannot be total and indiscriminate, without rigorous demands, and less being placed on an equal footing with those who have been trained to engage in the profession with those who have not (CEID-FECODE, 2002, REC, (61), p. 23). 